\title{
Scott River Hydrological and Nutrient Model construction and calibration
}

\author{
J. Hall \\ Water Science Branch, Department of Water, Western Australia \\ Email:joel.hall@water.wa.gov.au
}

\begin{abstract}
A numerical hydrological and nutrient export model has been developed for the Scott River catchment, with the objective of quantifying the water and nutrient inflows from the Scott River to the Hardy Inlet, and to examine the nutrient sources and timing of delivery. The model supported a water quality improvement plan for the Hardy Inlet. The modelling package Source Catchments (eWater 2010) was used to construct the Scott River model, which was calibrated at two flow gauging stations (one primary gauging station at the bottom of the catchment, and a secondary gauging station further upstream) and seven water quality sampling locations. Hydrological calibration was undertaken at the primary gauging station from 1 January 2000 - 31 December 2005. Validation was undertaken from 1 January 2006 - 11 November 2009, and at the secondary gauging station from 1 January 1996 - 14 April 1999. A model warm-up period of 1 year was included. Auto-calibration modules were not available in the version of Source Catchments used in the project, so AWBM was developed externally to the Source framework (in Microsoft Excel in this case), and automatic calibration optimization techniques were applied. The daily Nash-Sutcliffe efficiency (NSE) was used as the objective function for calibration. The primary gauging station achieved a daily NSE of 0.86 , a monthly NSE of 0.93 and a difference in measured and modeled runoff of $2 \%$. The validation at the same gauge achieved a daily NSE of 0.89 , a monthly NSE of 0.95 and a difference in measured and modeled total runoff of $2 \%$. The validation at the secondary gauging station achieved a daily NSE of 0.60 , a monthly NSE of 0.85 and a difference in total measured and modelled runoff of $23 \%$. The nutrient calibration was undertaken by adjusting the edge-of-paddock export concentration for each of the land-use types, within the bounds of measured data and relevant literature, until the measured and modelled winter median concentration for TN and for TP was within $10 \%$ of one another at each nutrient sampling location. This paper describes the steps involved in the construction and calibration of the Scott River hydrological and nutrient model.
\end{abstract}

Keywords: $\quad$ Source Catchments, water quality, nutrients, hydrology, Western Australia 


\section{INTRODUCTION}

A numerical hydrological and nutrient export model has been developed for the Scott River catchment, with the objective of quantifying the water and nutrient inflows from the Scott River to the Hardy Inlet, and to examine the nutrient sources and timing of delivery. The model was used to determine a cost/benefit analysis for a range of on-ground best management practices (BMPs) for the Scott River catchment. The model supports the Hardy Inlet water quality improvement plan. The Government of Western Australia has recognised the need for a water quality improvement plan (WQIP) for the Hardy Inlet, given the on-going deterioration of its water quality and frequent algal blooms. The inlet is located in the southern capes region of south-west Western Australia, and is highly valued for its environmental significance and recreational opportunities. This paper explores the steps involved in the construction and calibration of the model.

\section{CATCHMENT DESCRIPTION}

The Scott River catchment is located in south-west Western Australia, east of Augusta and south of the Brockman Highway. The west side of the catchment lies in the Shire of Augusta-Margaret River and the east lies in the Shire of Nannup. The hydrological and nutrient modelling discussed in this report uses the hydrographic catchment, which has an area of approximately $691 \mathrm{~km}^{2}$. The local government authority (LGA) boundaries, catchment boundaries, hydrology and major roads are shown in Figure 1.

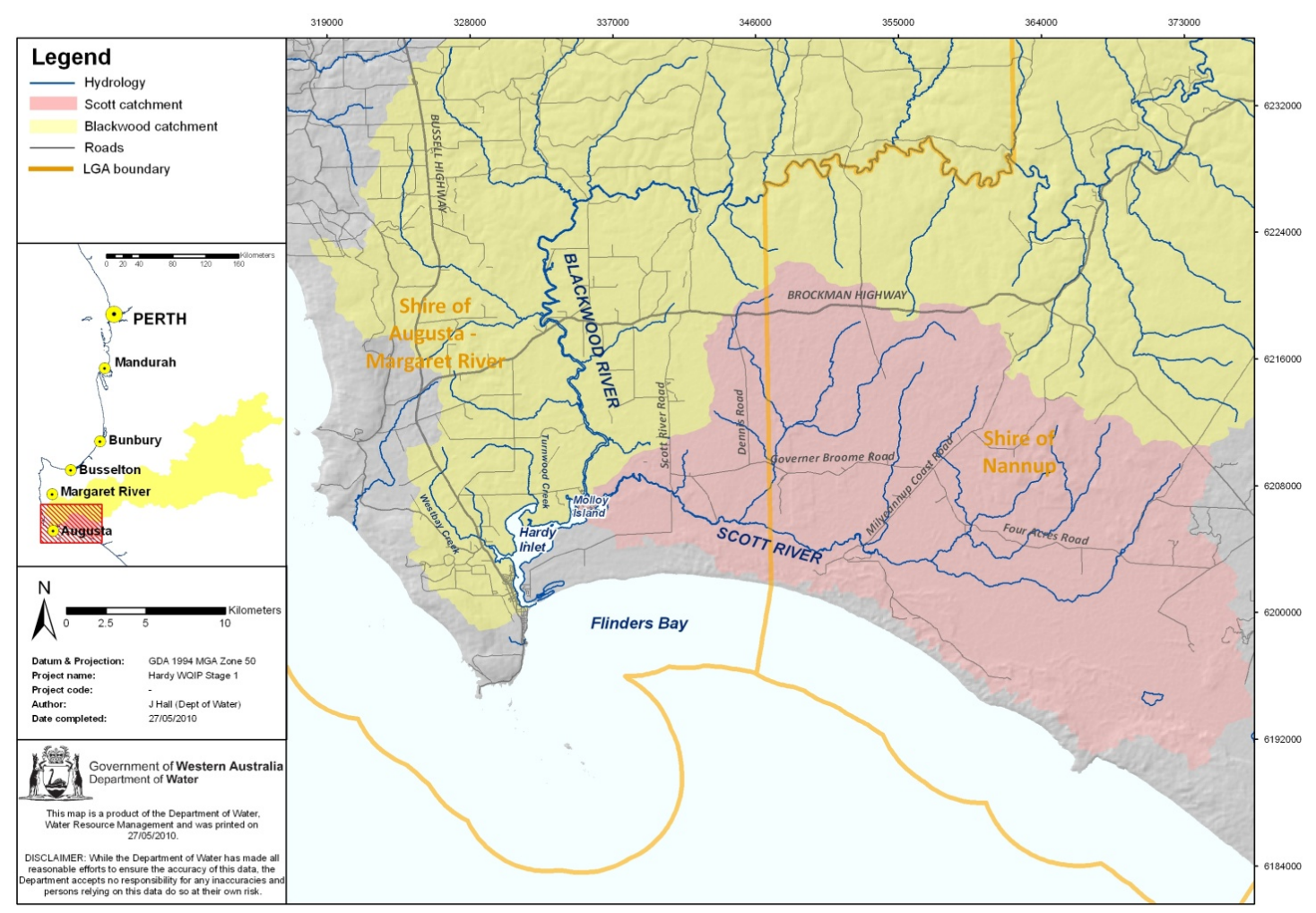

Figure 1. Location of the Scott River catchment (map courtesy of Department of Water)

\subsection{Hydrology and hydrogeology}

Most of the catchment and the main channel of the Scott River are located on the Scott Coastal Plain. The plain is characterized by relatively flat terrain and ephemeral waterways with cold wet winters and hot dry summers. The Scott River flows from east of the catchment to the west, where it discharges to the Hardy Inlet. The superficial aquifer on the Scott Coastal Plain is close to or at the ground surface in winter months. This results in significant water-logging, which is partially alleviated in paddocks by extensive rural drainage networks. The superficial aquifer is $20-30 \mathrm{~m}$ thick and overlies a series of confined and semiconfined aquifers. 


\subsection{Land use}

Most of the Scott River catchment is remnant natural vegetation (67\%), including national parks, nature reserves, state forest and foreshore reserves. The remainder is primarily agricultural land uses, mostly beef grazing, dairy farming and blue gum plantations. The land use is displayed in Figure 2.

\subsection{Flow and nutrient data}

Flow data is collected at two sites in the Scott River catchment, both in the river's main channel. The first is at Brennan's Ford (AWRC reference 609002) approximately $9 \mathrm{~km}$ upstream of the river's mouth - the most practical downstream location to measure flow without tidal or backwater effects. The Brennan's Ford gauging station measures streamflow from an area of $643 \mathrm{~km}^{2}$, approximately $93 \%$ of the Scott catchment. The average flow for the period 1969 to 2010 is $94.7 \mathrm{GL} / \mathrm{yr}$, however flow in the past decade $(2000-2009)$ is $35 \%$ lower than the average from $1970-2000$. A baseflow separation revealed that approximately $50 \%$ of the flow at Brennan's Ford (609002) is baseflow.

The second flow gauging station is at Milyeannup Bridge (AWRC reference 609026), approximately $12 \mathrm{~km}$ upstream of the Brennan's Ford gauging station. Milyeannup Bridge gauging station drains the eastern Scott catchment, an area of approximately $400 \mathrm{~km}^{2}$. The locations of the flow gauging stations are shown in Figure 2 .

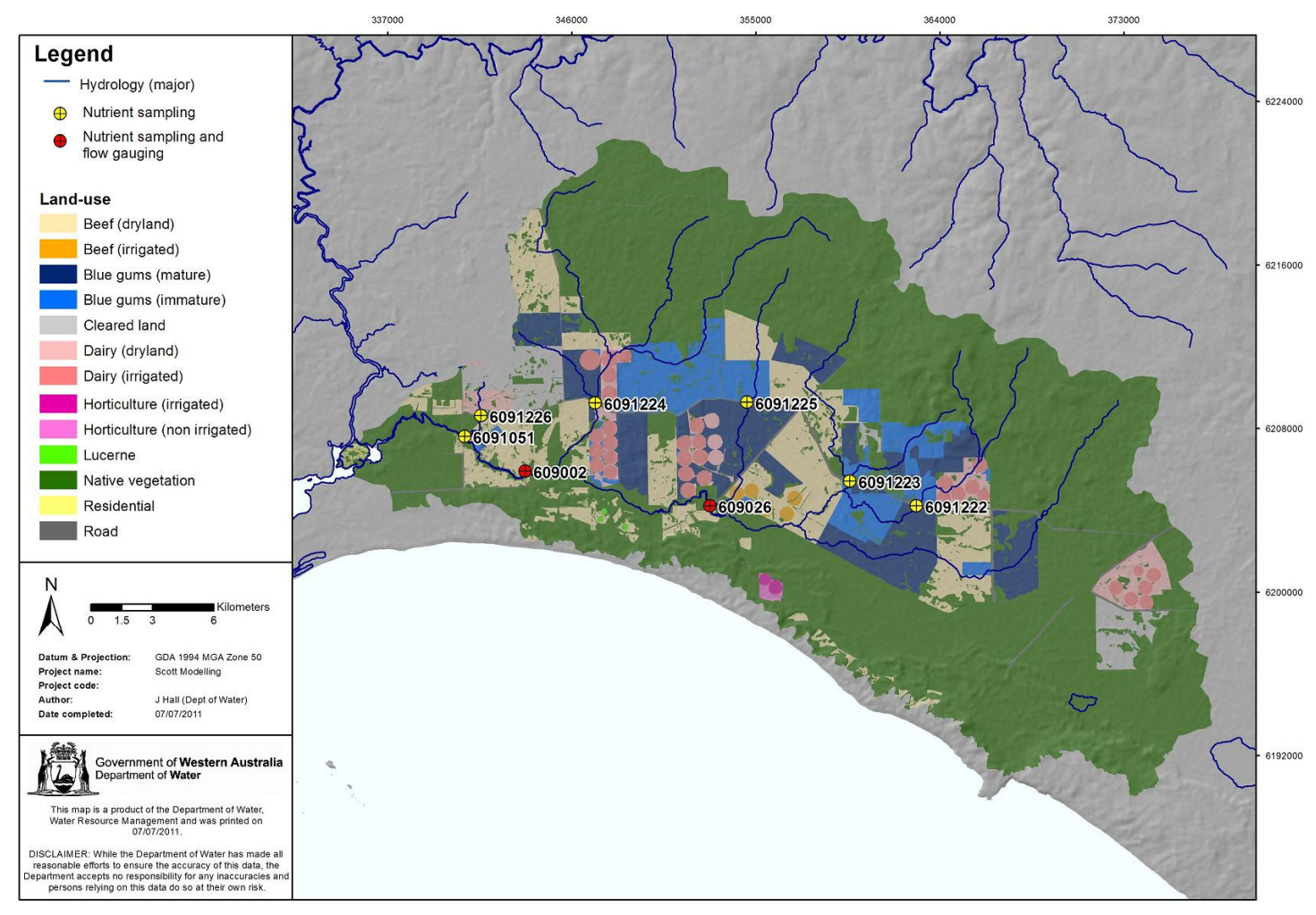

Figure 2. Land use, flow gauging and nutrient sampling locations (map courtesy of Department of Water)

Since 2000 the Department of Water has conducted regular water quality sampling (surface water) at eight sites in the Scott River catchment. Nutrient samples are collected fortnightly when the waterways are flowing (generally between May and November).

The nutrient status results for total phosphorus (TP) and total nitrogen (TN), for the most recent three years of sampling at each of the Scott River catchment's nutrient sampling locations, were calculated to estimate the current water nutrient status in various locations of the catchment. Using the Statewide River Water Quality Assessment classification (www.water.wa.gov.au/idelve/srwqa/), TN status is moderate to low in three of the eight sampling sites, and high to very high in the other five. TP was relatively higher in concentration than TN (when compared to guideline limits), with high to very high nutrient status in seven out of the eight sampling locations. 


\subsection{Conceptual model for water movement and nutrient transport}

The Scott River receives runoff primarily from rainfall, but also from irrigation returns. On the sandy coastal plain most of the rain will infiltrate into the soil, where it will either evaporate or percolate to the shallow water table. Over the course of the year the shallow water table will intersect the drain and riverbed levels and discharge to the waterways in late autumn/early winter. Associated soluble nutrients will be transported with this hydrological flux.

When the shallow water table is at the ground surface (usually around mid-winter) the rainfall will flow directly over the saturated ground surface, and will transport both particulate and soluble nutrients (saturated excess flow). Large rainfall events on the heavy soils to the northern part of the catchment will not have the opportunity to percolate into the groundwater, and will run off directly to the downstream waterways (infiltration-excess flow). This may happen on the sandy plain in extreme rainfall events, but is much less common. Nutrients delivered to the waterways (particulate and soluble) can either precipitate or adsorb to the channel sediments, be taken up by vegetation in the river channel or be transported along with the river flow. A conceptual diagram of the hydrological and nutrient processes in the Scott River catchment is shown in Figure 3.

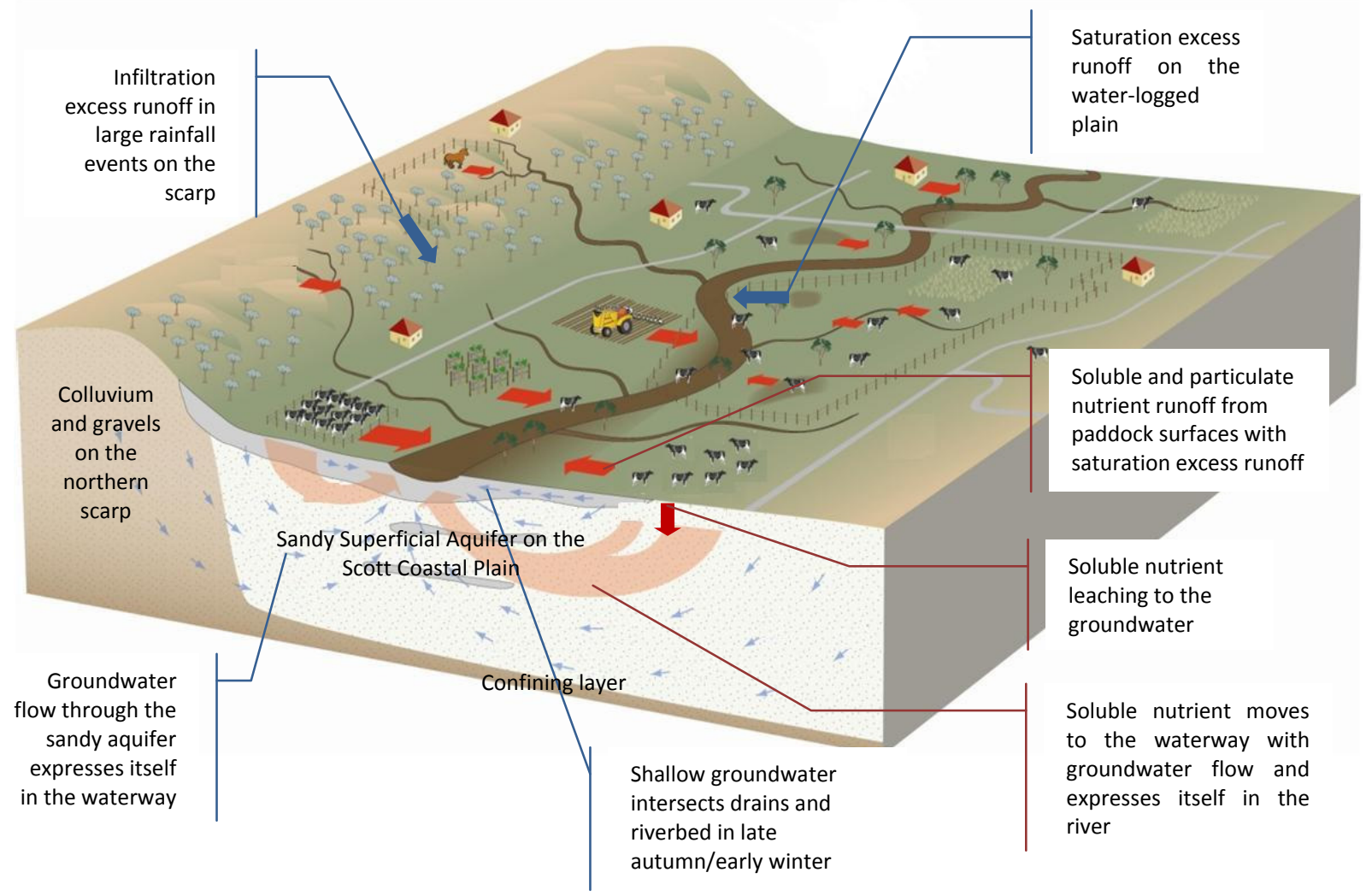

Figure 3. Scott River conceptual model (figure courtesy of Department of Water)

\section{MODEL CONSTRUCTION}

The model was constructed using the software package Source Catchments (eWater, 2010). Source Catchments was designed for hydrologic and constituent modelling at the whole-of-catchment scale. Source Catchments provides a flexible structure that allows users to select a level of model complexity appropriate to the problem at hand and within constraints imposed by available data and knowledge.

Source Catchments is a node-link style system for modelling water and constituent transport within the major channels in a catchment. Subcatchment boundaries can be determined based on stream topography and land forms calculated from a Digital Elevation Model (DEM). Subcatchments are connected via links and nodes that represent river and stream reaches and confluences, terminating at a catchment outlet. After generation and filtration, the constituents pass to a node before being routed and possibly processed along links.

The Australian Water Balance Model (AWBM) (Boughton 1996) was used to simulate the rainfall-runoff processes. AWBM is a catchment water balance model that relates runoff to rainfall with daily or hourly 
data, and calculates losses from rainfall for flood hydrograph modelling. The implementation of AWBM for the Scott River project was modelled at a daily time-step.

The constituent generation model selected for the Scott was the event mean concentration / dry weather concentration (EMC/DWC) model. Concentration runoff values for each land use type, are parameters that are usually adjusted during calibration of the Source Catchments model - however it is imperative that concentrations are within reasonable bounds and based on sound science and literature if the model is to accurately represent the catchment. The initial runoff concentration (EMC/DWC) was determined by dividing the estimated export load by the flow from each of the land uses. Export loads were estimated using a relationship between nutrient input and export, derived by the West Australian Department of Agriculture and Food's (DAFWA) Greener Pastures project (Lucey et al 2011). Nitrogen included fixation as an input, and fixation was set to $150 \mathrm{~kg} / \mathrm{ha}$ for irrigated pasture, $75 \mathrm{~kg} / \mathrm{ha}$ for non-irrigated pasture (Peoples et al, 1995), and $21 \mathrm{~kg} /$ ha for native vegetation (Lawrie, 1981).

\section{MODEL CALIBRATION AND VALIDATION}

The Scott River Source Catchments model is a medium-complexity model, and calibration to measured data before use (for prediction simulations) is a fundamental requirement. The calibration performance is presented in qualitative and quantitative terms in comparison with target criteria agreed upon by project managers and modelers, prior to the commencement of the modelling. The calibration criteria described below have been used to assess the calibration result:

- Qualitative measures:

- Visual inspection of modelled versus measured hydrographs for daily, monthly and annual flow data

- Visual inspection of plot of predicted versus measured median winter concentration values for TN and TP

- $\quad$ scattergram of measured versus modelled median winter concentration values for TN and TP.

- Quantitative measures:

- Daily Nash-Sutcliffe efficiency (NSE) of above 0.7 for calibration and above 0.6 for validation. Monthly NSE above 0.8 for calibration bores and above 0.7 for validation.

- $\quad$ the modelled versus observed winter median TP and TN values to be within $10 \%$ of one another at all sampling locations, and the total measured and modelled flow volume to be within $5 \%$.

\subsection{Hydrological calibration and validation}

Calibration was undertaken at the gauging station 609002 from 1 January 2000 - 31 December 2005. Validation was undertaken at the gauging station 609002 from 1 January $2006-11$ November 2009, and at the secondary gauging station 609026 from 1 January 1996 - 14 April 1999. A model warm-up period of 1 year was included pre-calibration. Auto-calibration modules were not available in the version of Source Catchments used in the project, so AWBM was developed externally to the Source framework (in Microsoft Excel in this case), and automatic calibration optimisation techniques could be applied. The daily NSE was used as the objective function for calibration. Both gauging stations achieved acceptable criteria for calibration and validation; calibration and validation metrics are shown in Table 1. The predicted water balance was within $5 \%$ of the observed water balance, and satisfied the flow criteria. 
Table 1. Calibration and validation statistics

\begin{tabular}{|c|c|c|c|c|c|c|c|c|c|}
\hline \multirow[t]{2}{*}{ Statistic } & \multirow{2}{*}{$\begin{array}{l}\text { Measured } \\
\text { flow } \\
(609002)\end{array}$} & \multicolumn{2}{|c|}{$\begin{array}{c}\text { Calibration } \\
(609002)\end{array}$} & \multirow{2}{*}{$\begin{array}{l}\text { Measured } \\
\text { flow } \\
(609002)\end{array}$} & \multicolumn{2}{|c|}{$\begin{array}{c}\text { Validation } \\
(609002)\end{array}$} & \multirow{2}{*}{$\begin{array}{c}\text { Measured } \\
\text { flow } \\
(609026)\end{array}$} & \multicolumn{2}{|c|}{$\begin{array}{c}\text { Validation } \\
(609026)\end{array}$} \\
\hline & & value & \%dif & & value & \%dif & & value & $\%$ dif \\
\hline Period: & \multicolumn{2}{|c|}{$1 / 1 / 2000-31 / 12 / 2005$} & - & \multicolumn{2}{|c|}{$1 / 1 / 2006-9 / 11 / 2009$} & - & \multicolumn{2}{|c|}{ 1/1/1996 - 14/4/1999 } & - \\
\hline$n$ & 2192 & - & - & 1409 & - & - & 1199 & - & - \\
\hline NSE daily & - & 0.86 & - & - & 0.89 & - & - & 0.60 & - \\
\hline NSE monthly & - & 0.93 & - & - & 0.95 & - & - & 0.85 & - \\
\hline Total runoff (GL) & 387 & 381 & $2 \%$ & 273 & 279 & $-2 \%$ & 171 & 209 & $-23 \%$ \\
\hline Summer runoff (GL) & 2 & 7 & $>100 \%$ & 5.2 & 5.8 & $-12 \%$ & 2 & 2 & $-5 \%$ \\
\hline Winter runoff (GL) & 385 & 374 & $3 \%$ & 267.6 & 273.6 & $-2 \%$ & 169 & 207 & $-23 \%$ \\
\hline Average flow (ML/day) & 177 & 174 & $2 \%$ & 193.6 & 198.3 & $-2 \%$ & 142 & 174 & $-23 \%$ \\
\hline Median flow (ML/day) & 1 & 18 & $>100 \%$ & 4.5 & 11.0 & $>100 \%$ & 8 & 2 & $80 \%$ \\
\hline 75 percentile flow (ML/day) & 201 & 207 & $-3 \%$ & 187.1 & 206.4 & $-10 \%$ & 148 & 249 & $-68 \%$ \\
\hline 90 percentile flow (ML/day) & 576 & 557 & $3 \%$ & 674.8 & 661.6 & $2 \%$ & 509 & 543 & $-7 \%$ \\
\hline Max flow (ML/day) & 3134 & 2447 & $22 \%$ & 4704.9 & 2882.8 & $39 \%$ & 2171 & 2942 & $-35 \%$ \\
\hline
\end{tabular}

\subsection{Nutrient calibration}

Source Catchments produces daily nutrient concentration results. However, due to the large variability in the measured data, and because summer flows cease, resulting in highly erratic nutrient concentration values, the median winter concentrations were used for calibration. The nutrient calibration was undertaken by adjusting the edge-of-paddock export concentration for each of the land-use types, within the bounds of measured data and relevant literature, until the measured and modelled winter median concentration for TN and for TP was within $10 \%$ of one another at each nutrient sampling location.

The nutrient calibration achieved the criteria, with measured and modelled winter median concentrations within $10 \%$ at all seven of the nutrient sampling locations. The predicted and observed winter median concentrations for each of the sampling locations are shown in Table 2.

Table 2. Observed and predicted concentrations at each of the nutrient sampling locations

\begin{tabular}{ccccccc}
\hline $\begin{array}{c}\text { Site } \\
\text { (AWRC ref.) }\end{array}$ & $\begin{array}{c}\text { TP observed } \\
(\mathbf{m g} / \mathrm{L})\end{array}$ & $\begin{array}{c}\text { TP predicted } \\
(\mathbf{m g} / \mathrm{L})\end{array}$ & $\begin{array}{c}\text { Difference } \\
(\%)\end{array}$ & $\begin{array}{c}\text { TN observed } \\
(\mathbf{m g} / \mathrm{L})\end{array}$ & $\begin{array}{c}\text { TN predicted } \\
(\mathbf{m g} / \mathrm{L})\end{array}$ & $\begin{array}{c}\text { Difference } \\
(\%)\end{array}$ \\
\hline 609002 & 0.15 & 0.15 & $0.7 \%$ & 1.00 & 1.00 & $-0.2 \%$ \\
609026 & 0.18 & 0.16 & $6.3 \%$ & 1.40 & 1.46 & $-4.0 \%$ \\
6091226 & 0.14 & 0.15 & $-5.7 \%$ & 1.75 & 1.73 & $1.1 \%$ \\
6091224 & 0.04 & 0.04 & $3.4 \%$ & 1.20 & 1.17 & $2.4 \%$ \\
6091225 & 0.15 & 0.15 & $-0.7 \%$ & 1.60 & 1.59 & $0.4 \%$ \\
6091223 & 0.15 & 0.14 & $2.8 \%$ & 1.40 & 1.38 & $1.4 \%$ \\
6091222 & 0.68 & 0.68 & $0.4 \%$ & 2.20 & 2.15 & $2.2 \%$ \\
\hline
\end{tabular}

Modelled edge-of-paddock runoff and nutrient export values are displayed in Table 6. Values were consistent with measured and published values from the Swan Coastal Plain. Stewart (2010) measured runoff values for south-west Western Australian blue gum plantations of $0.24 \mathrm{mg} / \mathrm{L} \mathrm{TP}$ (14 samples with a standard deviation of $0.81 \mathrm{mg} / \mathrm{L})$ and $1.81 \mathrm{mg} / \mathrm{L}$ for $\mathrm{TN}(14$ samples with a standard deviation of 2.87 $\mathrm{mg} / \mathrm{L})$. The same paper has pasture measured at $0.61 \mathrm{mg} / \mathrm{L} \mathrm{TP}(22$ samples with a standard deviation of $0.82 \mathrm{mg} / \mathrm{L}$ ) and $3.56 \mathrm{mg} / \mathrm{L}$ TN (22 samples with a standard deviation of $3.65 \mathrm{mg} / \mathrm{L}$ ). Remnant vegetation had a median TN value of $0.71 \mathrm{mg} / \mathrm{L}$ (11 samples with a standard deviation of 0.15 ). Young (1995) reported export loads in Western Australian catchments for improved pasture of $0.5-1.9 \mathrm{~kg} / \mathrm{ha} / \mathrm{year}$ for TP and $2.4-3.5 \mathrm{~kg} / \mathrm{ha} /$ year for $\mathrm{TN}$. The same paper reported market garden exports (in south-eastern Australia) of $2.7-14.3 \mathrm{~kg} / \mathrm{ha} / \mathrm{yr}$ for TP and $20-34.5 \mathrm{~kg} / \mathrm{ha} / \mathrm{yr}$ for TN. DAFWA has collected a large number of TP and TN samples from edge-of-paddock runoff for dryland beef, irrigated dairy, and dryland dairy land uses in south-west Western Australia (Lucey et al, 2011). Between 230 and 570 nutrient samples were collected for analysis from each of the land uses between the years $2003-2009$. TN rates for dryland beef had a median of $2.7 \mathrm{mg} / \mathrm{L}$, while irrigated dairy had a median concentration of $6.7 \mathrm{mg} / \mathrm{L}$ and dryland dairy of between 6 and $10 \mathrm{mg} / \mathrm{L}$ depending on the fertilisation rate. TP rates for dryland beef had a median 
of $0.6 \mathrm{mg} / \mathrm{L}$, with irrigated dairy having a median runoff rate of $0.45 \mathrm{mg} / \mathrm{L}$ and dryland dairy 0.7 to 1.10 $\mathrm{mg} / \mathrm{L}$ depending on nitrogen fertilisation rates.

Table 3. Observed and predicted concentrations at each of the nutrient sampling locations

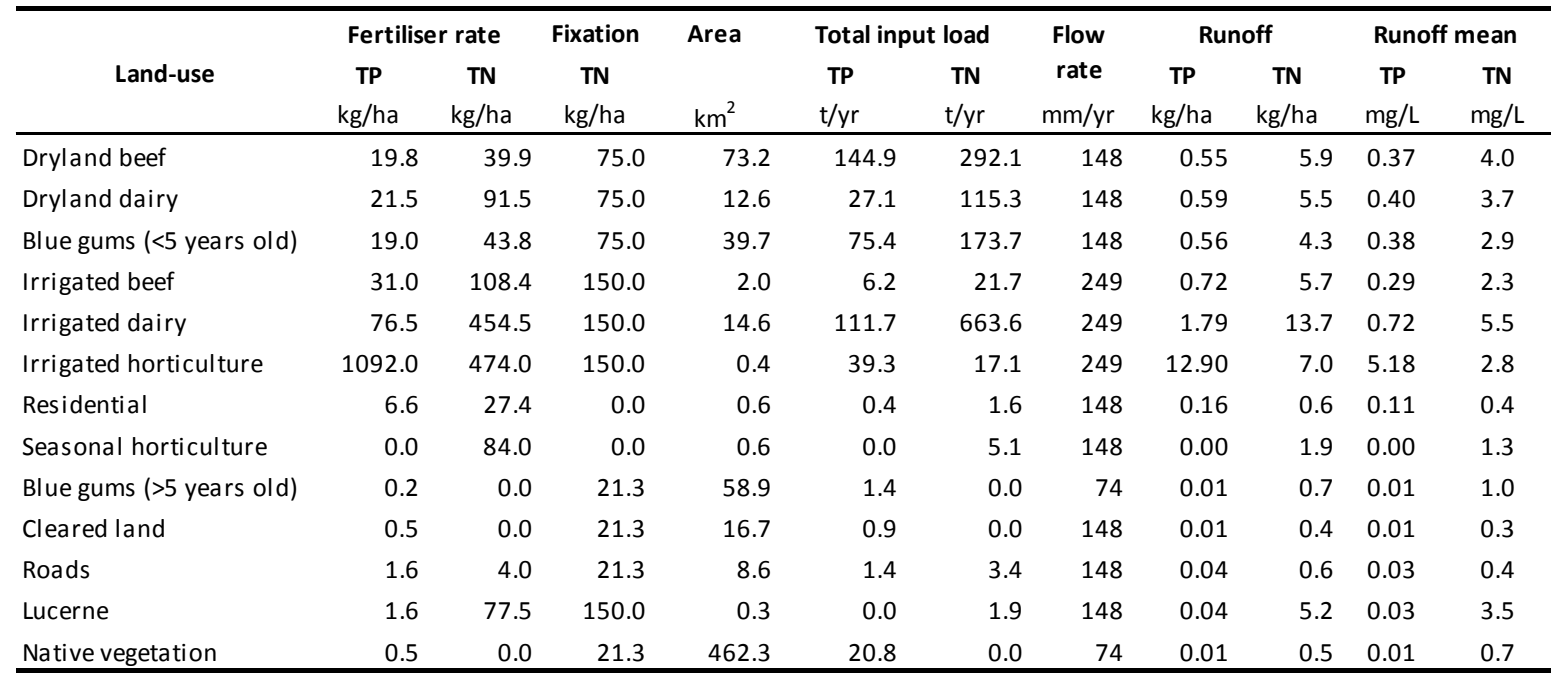

\section{DISCUSSION AND CONCLUSIONS}

A hydrological and nutrient model was developed for the Scott River catchment in the south-west of Western Australia. The model was constructed using the software package Source Catchments by eWater, and used available rainfall, evaporation, topographical, flow and nutrient sampling data. The Australian Water Balance Model (AWBM) was implemented as the rainfall-runoff model. This was required to be developed and calibrated external to Source Catchments, due to the lack of an auto-calibration procedure in this version of Source Catchments. The daily NSE value of $>0.85$ for gauging station 609002 indicates a good calibration and validation at this location; however the validation at the upstream gauge (609026) achieved a NSE of 0.60 , which indicates a fair to average result. It is likely that the model would benefit from a more complex rainfall-runoff model to achieve a better validation result at this gauge. TN and TP concentrations were calibrated by adjusting nutrient export concentrations, within the bounds of the collected data and literature, to match the modelled with measured nutrient concentration values in the waterways. The modelled and observed winter median concentration values were within $10 \%$ of one another at all nutrient sampling locations. The calibrated model could then be used to quantify the water and nutrient inflows from the Scott River to the Hardy Inlet, and to examine the nutrient sources, and predict the results of land use changes at a catchment scale.

\section{REFERENCES}

eWater CRC (2010). Source Catchments User Guide, eWater Cooperative Research Centre, Canberra, Australia.

Department of Agriculture (2000). Guidelines for managing dairy effluent in Western Australia, Bulletin 4336; Department of Agriculture, Western Australia.

Lawrie, A.C. (1981). Nitrogen fixation by native Australian legumes, Australian Journal of Botany 1981, $29,143-57$

Lucey, J., Bolland, M., Bennett, D., Morris, R., Russel, B., Staines, M., (2011). The Greener Pasture Project: Managing nutrients on dairy pastures, Department of Agriculture and Food, ISSN: 1833-7236, February 2011.

Peoples, M.B., Herridge, D.F. \& Ladha, J.K. (1995). Biological nitrogen fixation: An efficient source of nitrogen for sustainable agricultural production?, Journal of Plant and Soil, 174: 3 - 28.

Stewart, B.A. (2010). An assessment of the impacts of timber plantations on water quality and biodiversity values of Marbellup Brook, Western Australia, Environmental Monitoring and Assessment 10.1007/s10661-010-1436-1.

Young, W.J., Marston, F.M. \& Davis, J.R. (1995). Nutrient exports and land use in Australian Catchments, Journal of Environmental Management, 47, 165 - 183. 